\title{
FORMATION PECULIARITIES OF IRON (III) ACETATE: POTENTIAL PRECURSOR FOR IRON METAL-ORGANIC FRAMEWORKS (MOFs)
}

\author{
A. Laurikėnas ${ }^{\text {a }}$, J. Barkauskas ${ }^{\text {a }}$, J. Reklaitis ${ }^{\text {b }}$, G. Niaura ${ }^{c}$, D. Baltrūnas ${ }^{\text {b }}$, and A. Kareiva ${ }^{\text {a }}$ \\ ${ }^{a}$ Department of Inorganic Chemistry, Vilnius University, Naugarduko 24, LT-03225 Vilnius, Lithuania \\ ${ }^{b}$ Institute of Physics, Center for Physical Sciences and Technology, Savanoriu 231, LT-02300 Vilnius, Lithuania \\ ' Institute of Chemistry, Center for Physical Sciences and Technology, A. Goštauto 9, LT-01108 Vilnius, Lithuania \\ E-mail: andrius.laurikenas@chf.vu.lt
}

Received 7 September 2015; revised 31 October 2015; accepted 25 March 2016

\begin{abstract}
In this study, iron (III) acetate was synthesized using acetic acid/hydrogen peroxide type synthesis. The obtained material was characterised using thermogravimetric analysis (TG), X-ray diffraction (XRD) analysis, scanning electron microscopy (SEM) coupled with energy-dispersive X-ray spectroscopy (EDX), infrared (IR) spectroscopy and Mössbauer spectroscopy. The chemical composition, microstructure and properties of iron (III) acetate were investigated and discussed. The results of XRD analysis showed that the synthesized iron (III) acetate is amorphous. The obtained iron (III) acetate is a potential candidate as a precursor for the synthesis of iron metal-organic frameworks (MOFs).
\end{abstract}

Keywords: TG analysis, SEM, XRD, FTIR spectroscopy, Mössbauer spectroscopy, iron acetate, MOFs

PACS: 81.05.-t, 81.16.Be, 81.20.Ka, 81.90.+c

\section{Introduction}

Iron(III)acetate is a coordination compound morecommonly known as a basic iron acetate. With the formula of $\left[\mathrm{Fe}_{3} \mathrm{O}(\mathrm{OAc})_{6}\left(\mathrm{H}_{2} \mathrm{O}\right)_{3}\right] \mathrm{OAc},\left(\mathrm{OAc}\right.$ is $\left.\mathrm{CH}_{3} \mathrm{CO}_{2}^{-}\right)$it is a salt, composed of the cation $\left[\mathrm{Fe}_{3}\left(\mu^{3} \mathrm{O}\right)(\mathrm{OAc})_{6}\left(\mathrm{H}_{2} \mathrm{O}\right)_{3}\right]^{+}$ and acetate $\mathrm{CH}_{3} \mathrm{CO}_{2}{ }^{-}$anion [1] . Reduction of the cation affords the neutral mixed-valence derivative that contains one ferrous and two ferric centres. Former investigations revealed that iron (III) acetate is a trinuclear cluster [1, 2]. The Fe centres are equivalent, each being octahedral and bound to six oxygen ligands, including a triply bridging oxide at the centre of the equilateral triangle $[3,4]$.

Iron (III) acetate was used as a starting material for the preparation of nearly monodispersed superparamagnetic maghemite nanoparticles [5]. The as-prepared particles were exploited for the development of magnetic nanocomposites with possible applicability in medicine and biochemistry. Single-molecule magnets have important technological applications in information storage and quantum computation. Recent experimental results indicated that $\mathrm{Mn}$ and Fe acetates showed the physical properties of molecular nanomagnets [6]. Recently, it was demonstrated that iron (III) acetate is one of the best precursors for the impreg- nation of a commercial activated carbon which was evaluated as the best catalyst in the removal of the azodye Orange II from water [ [ ] and for the fabrication of next-generation iron-based phosphate binders [8]. The processes of thermal decomposition of iron acetates are used for the production of hematite which is one of the most investigated oxides for energy applications, protein adsorption, and specifically for photocatalysis [9], 10]. Similar processing is used for the fabrication of hematite nanoparticles and nanocubes, high quality magnetite/carbon core-shell and shell-core nanoparticles and porous magnetite nanospheres [11-15]. A trinuclear iron acetate precursor was used for the synthesis of new iron-cobalt clusters [16]. The investigations revealed the presence of $\mathrm{Fe}^{3+}$ ions in high spin state and having the close environment. The results of the thermogravimetric analysis, however, indicated improving in the thermal stability by replacing acetate anions with silicon-containing carboxyl ligands. This widens the temperature range in which such compounds can be used in practical applications. The catalytic activity of similar clusters was dependent on the properties of starting materials [17, 18]. The macrocyclic complexes of the type $\left[\mathrm{M}\left(\mathrm{C}_{36} \mathrm{H}_{36} \mathrm{~N}_{4}\right) \mathrm{X}\right] \mathrm{X}_{2}$, where $\mathrm{M}=\mathrm{Fe}(\mathrm{III})$ and $\mathrm{X}=\mathrm{Cl}^{-}$, $\mathrm{NO}_{3}^{-}$, and $\mathrm{CH}_{3} \mathrm{COO}^{-}$were synthesized by the template 
method in the presence of trivalent metal salts [19]. The in vitro antimicrobial and antioxidant activities of metal complexes were evaluated and found to be dependent on the nature of the anion. Mononuclear, dimeric and polymeric iron complexes with conjugated ligands also showed different magnetic, thermal, mesomorphic and thermoelectric properties [20]. These observations clearly show the influence of the precursor on the properties of the final synthesis product.

Metal-organic frameworks (MOFs) have received great attention in different applications. The specific cation exchange behaviour between $\mathrm{Fe}^{3+}$ and the framework $\mathrm{Al}^{3+}$ allows highly sensitive detection of $\mathrm{Fe}^{3+}$ in an aqueous solution [21]. However, the selectivity of the developed method and the stability of MOFs might be dependent on the nature of the precursor. It was also demonstrated that the physical properties of iron (III) carboxylate MOFs depend significantly on the synthesis method [22, 23]. Moreover, the magnetic properties of iron associated magnetic metal-organic framework nanoparticles depend on the morphological features of precursors and MOFs [24]. Thus, several approaches could be used for the synthesis of iron acetate as a precursor for MOFs. However, most of these methods suffer from a number of disadvantages, such as small quantities of the product, and the assembly of nanostructures is usually a secondary process. Besides, complex architectures are often found among metalorganic framework compounds 25, 26]. The mixedmetal approach to this type of materials offers an additional degree of structural complexity, and a potential tunability of their properties, which remains largely unexplored. Herein, we present a facile and large-scale synthesis of iron (III) acetate as a precursor for the porous mixed-valence, iron metal-organic frameworks (MOFs) in "solvent-free" type synthesis. Our approach is based on acetic acid/hydrogen peroxide type synthesis and additional recrystallization.

\section{Experiment}

\subsection{Materials and instruments}

All chemicals were purchased from Merck and Sigma Aldrich. Thermogravimetric analyses were conducted using a simultaneous thermal analyser 6000 (PerkinElmer) and Pyris software. Infrared spectra (1800$450 \mathrm{~cm}^{-1}$ ) of powdered samples were taken using a Frontier FT-IR (PerkinElmer) spectrometer. X-ray diffraction patterns were recorded using a MiniFlex II diffractometer (Rigaku). The morphology of particles was investigated using a scanning electron microscope (SEM) Hitachi SU-70. The Mössbauer spectra were recorded with a Mössbauer spectrometer (Wis- senschaftliche Elektronik $\mathrm{GmbH}$ ) at room temperature using the source of ${ }^{57} \mathrm{Co}$ in the rhodium matrix.

\subsection{Synthesis of $\left[\mathrm{Fe}_{3} \mathrm{O}\left(\mathrm{O}_{2} \mathrm{C}-\mathrm{CH}_{3}\right)_{6}\left(\mathrm{H}_{2} \mathrm{O}\right)_{3}\right] \mathrm{O}_{2} \mathrm{C}-\mathrm{CH}_{3}$}

For the preparation of iron (III) acetate, acetic acid/hydrogen peroxide type synthesis was chosen for its simplicity. $11.2 \mathrm{~g}$ of iron powders were placed in a beaker and $12 \mathrm{ml}$ of $50 \%$ acetic acid are added. The reaction mixture was heated to $75^{\circ} \mathrm{C}$ and mixed till metallic iron fully reacted with acetic acid and the colour of the mixture turned to green. Next, $6 \mathrm{ml}$ of $30 \%$ hydrogen peroxide were added to oxidise $\mathrm{Fe}^{2+}$ ions to $\mathrm{Fe}^{3+}$. The obtained mixture was filtered and the solvent was evaporated. $2.95 \mathrm{~g}$ of dark red crystals were obtained, the yield was $81 \%$.

\subsection{Recrystallization of $\left[\mathrm{Fe}_{3} \mathrm{O}\left(\mathrm{O}_{2} \mathrm{C}-\mathrm{CH}_{3}\right)_{6}\left(\mathrm{H}_{2} \mathrm{O}\right)_{3}\right]_{2} \mathrm{O}_{2}-\mathrm{CH}_{3}$}

Crude iron (III) acetate crystals were purified by recrystallization. $1 \mathrm{~g}$ of crude iron (III) acetate crystals was placed into a $250 \mathrm{ml}$ beaker, and $100 \mathrm{ml}$ of $96.5 \%$ ethanol was added. The mixture was heated to $70{ }^{\circ} \mathrm{C}$ and mixed on a magnetic stirrer. The most part of iron (III) acetate was dissolved. The solution was then filtered through a fine paper filter. The filtrate was centrifuged at $5200 \mathrm{rpm}$ for $5 \mathrm{~min}$. The resulted clear dark red solution was poured on an evaporating dish and air-dried. $0.4 \mathrm{~g}$ of shiny dark red crystals were obtained, the yield was $40 \%$.

\subsection{Synthesis of $\mathrm{Fe}_{3} \mathrm{O}\left(\mathrm{F}_{4} \mathrm{BDC}\right)_{3}\left(\mathrm{H}_{2} \mathrm{O}\right)_{3} \cdot(\mathrm{DMF})_{3.5}$}

Iron (III) acetate was further used in the metal-organic framework synthesis. Triethylamine was diffused into a solution of 2,3,4,5-tetrafluorbenzene-1,4-dicarboxylic acid $(0.04 \mathrm{~g}, 0.15 \mathrm{mmol})$ and iron (III) acetate $(0.125 \mathrm{~g}, 0.15 \mathrm{mmol})$ in an ethanol/ $\mathrm{N}, \mathrm{N}$-dimethylformamide (DMF) (1:1 v/v) mixture. The solution was kept in a $2 \mathrm{ml}$ glass vial covered with a plastic cap, one hole punctured in a rubber seal for slower diffusion. The atmosphere of triethylamine was created by placing the beaker with triethylamine in a dessicator. The vial was kept in the dessicator for 2 weeks.

The precipitated red powders of $\mathrm{Fe}_{3} \mathrm{O}\left(\mathrm{F}_{4} \mathrm{BDC}\right)_{3}$ $\left(\mathrm{H}_{2} \mathrm{O}\right)_{3} \cdot(\mathrm{DMF})_{3.5}$ were filtered and washed with DMF $(3 \times 5 \mathrm{ml})$ and hexane $(3 \times 5 \mathrm{ml})$. The yield was $0.008 \mathrm{~g}$, $\sim 2 \%$. The precipitate is slightly soluble in water, but stable in organic solvents.

\section{Results and discussion}

The thermal decomposition behaviour of the synthesized iron (III) acetate was investigated using 


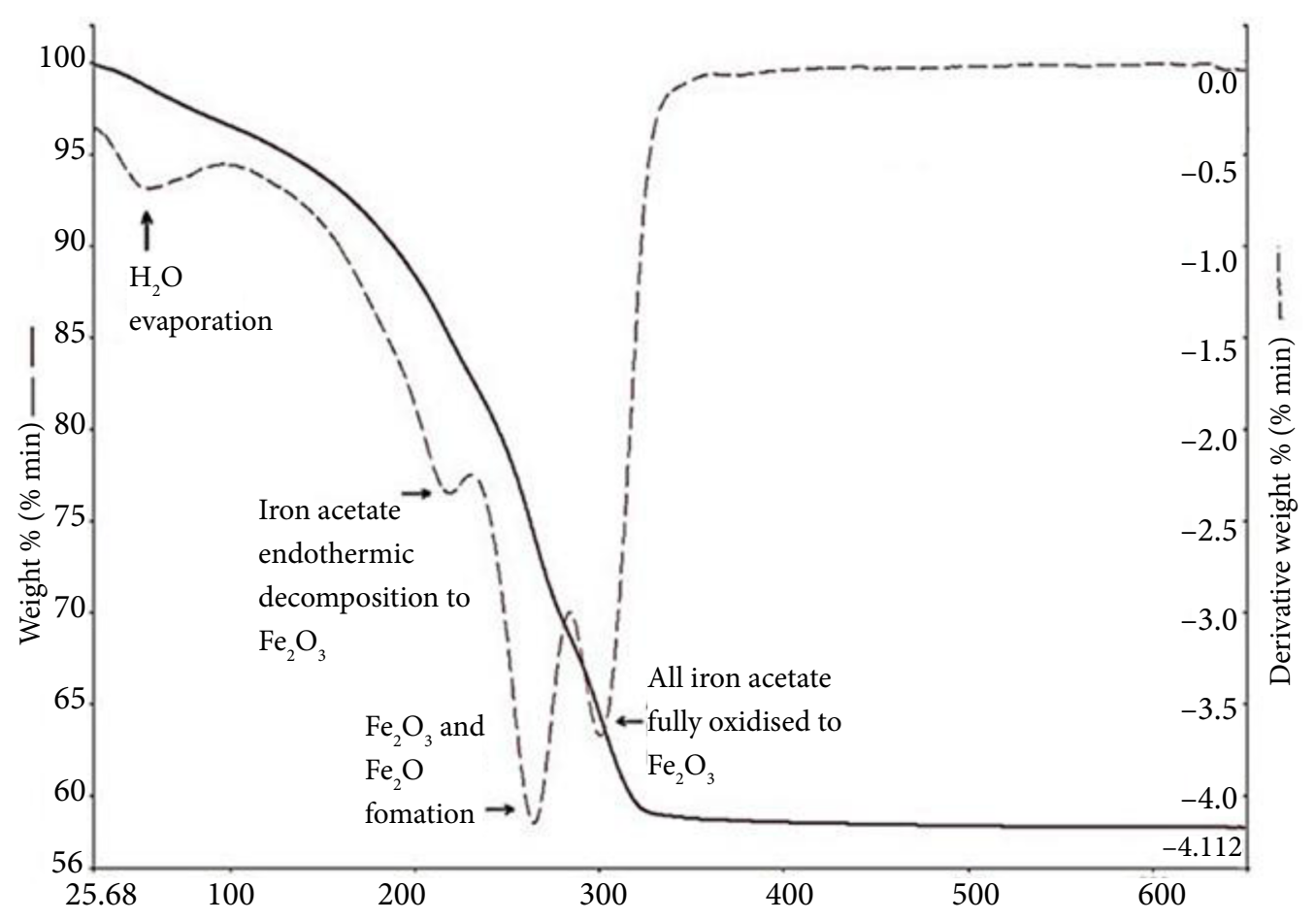

Fig. 1. TG-DTG curves of synthesized and recrystallized iron (III) acetate.

thermogravimetric (TG) analysis by heating the sample at a heating rate of $10^{\circ} \mathrm{C} / \mathrm{min}$ in air atmosphere. The TG-DTG curves of iron (III) acetate are shown in Fig. 1. The first weight loss of about $2 \%$ in the TG curve was observed from room temperature to about $100^{\circ} \mathrm{C}$, and it is due to the evaporation of residual water in the sample. A rapid mass loss continuously occurs with increasing the temperature up to $320^{\circ} \mathrm{C}$. This abrupt weight loss is associated with the decomposition of iron (III) acetate, but the oxidation of $\mathrm{Fe}(\mathrm{II})$ to $\mathrm{Fe}(\mathrm{III})$ occurs [27]:

$$
\begin{aligned}
& 6 \mathrm{Fe}\left(\mathrm{CH}_{3} \mathrm{COO}\right)_{3} \\
& \rightarrow 2 \mathrm{Fe}_{3} \mathrm{O}_{4}+9 \mathrm{CH}_{3} \mathrm{COCH}_{3}+9 \mathrm{CO}_{2}+1 / 2 \mathrm{O}_{2}, \\
& 4 \mathrm{Fe}\left(\mathrm{CH}_{3} \mathrm{COO}\right)_{3} \\
& \rightarrow 2 \mathrm{Fe}_{2} \mathrm{O}_{3}+6 \mathrm{CH}_{3} \mathrm{COCH}_{3}+6 \mathrm{CO}_{2}, \\
& 2 \mathrm{Fe}_{3} \mathrm{O}_{4}+1 / 2 \mathrm{O}_{2} \rightarrow 3 \mathrm{Fe}_{2} \mathrm{O}_{3} .
\end{aligned}
$$

Afterwards, the weight remains constant and that indicates that the decomposition of iron (III) acetate has been completed below $320^{\circ} \mathrm{C}$.

The phase crystallinity and purity of the synthesized sample were characterized by means of $\mathrm{X}$-ray diffraction (XRD) analysis. The powder XRD pattern of synthesised and recrystallized iron (III) acetate is given in Fig. 2 .

The results of the X-ray diffraction analysis evidently show that complete crystallization of iron (III) acetate does not take place during the recrystallization, and the synthesised iron (III) acetate is partially amorphous.

The Fourier transform infrared (FTIR) spectrum of the synthesised and recrystallized iron (III) acetate is presented in Fig. 3. The assignments of the iron (III) acetate bands observed in the infrared spectrum are summarized in Table 1 .

The difference between the $v_{\mathrm{a}}\left(\mathrm{COO}^{-}\right)$and $v_{\mathrm{s}}\left(\mathrm{COO}^{-}\right)$ modes is $108 \mathrm{~cm}^{-1}$, which is slightly larger than the ionic value $\left(137 \mathrm{~cm}^{-1}\right)$. Therefore, the formation of a bridging trinuclear iron complex might be suggested from

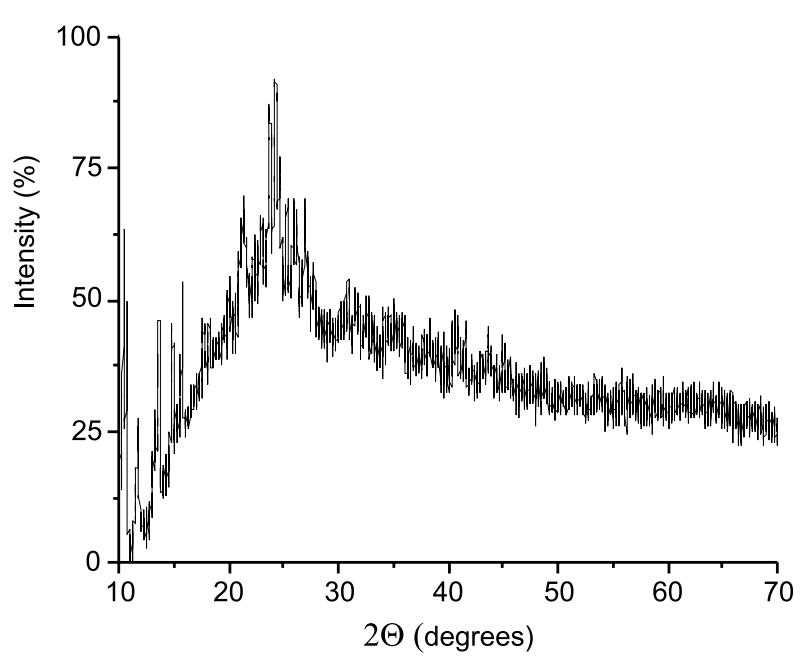

Fig. 2. The XRD pattern of synthesized and recrystallized iron (III) acetate. 


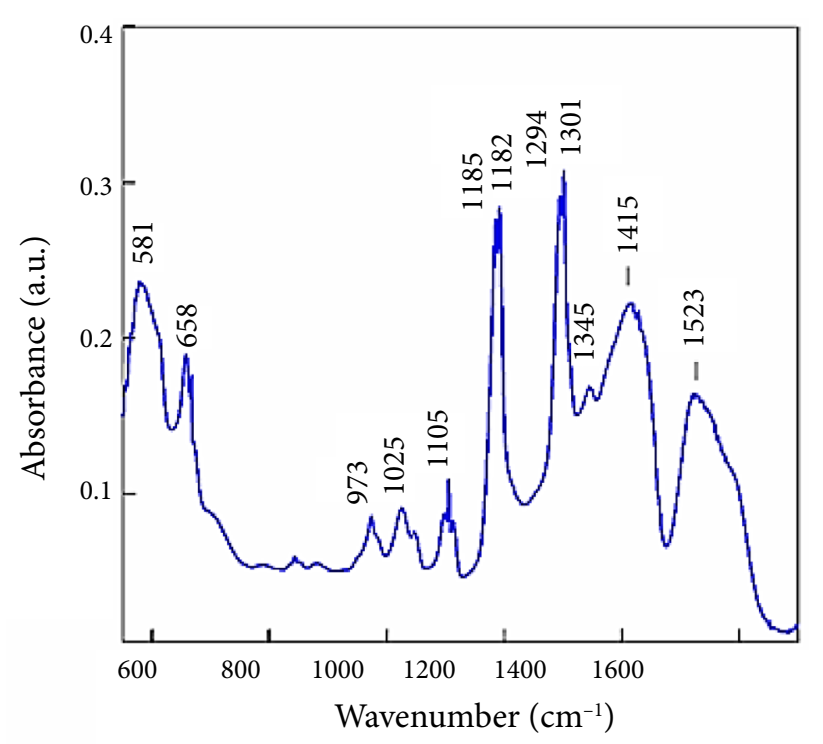

Fig. 3. The FTIR spectrum of synthesised and recrystallized iron (III) acetate.

Table 1. Assignments of the iron (III) acetate bands observed in the FTIR spectrum. Abbreviations: $v$, stretching; $\delta$, deformation; $\rho$, rocking; oop, out-of-plane; ip, inplane; s, symmetric; a, asymmetric.

\begin{tabular}{ccc}
\hline Acetate anion & Iron (III) acetate & $\begin{array}{c}\text { Assignments } \\
{[29-32]}\end{array}$ \\
\hline 1553 & 1523 & $v_{\mathrm{a}}\left(\mathrm{COO}^{-}\right)$ \\
\hline 1416 & 1415 & $v_{\mathrm{s}}\left(\mathrm{COO}^{-}\right)$ \\
\hline 1347 & 1345 & $\delta\left(\mathrm{CH}_{3}\right)$ \\
\hline- & 1047 & $\rho_{\text {oop }}\left(\mathrm{CH}_{3}\right)$ \\
\hline 1020 & 1025 & $\rho_{\text {ip }}\left(\mathrm{CH}_{3}\right)$ \\
\hline 928 & 973 & $v\left(\mathrm{C}-\mathrm{C}^{-}\right)$ \\
\hline- & 658 & $\delta\left(\mathrm{COO}^{-}\right)$ \\
\hline- & 581 & $\rho_{\text {oop }}\left(\mathrm{COO}^{-}\right)$ \\
\hline
\end{tabular}

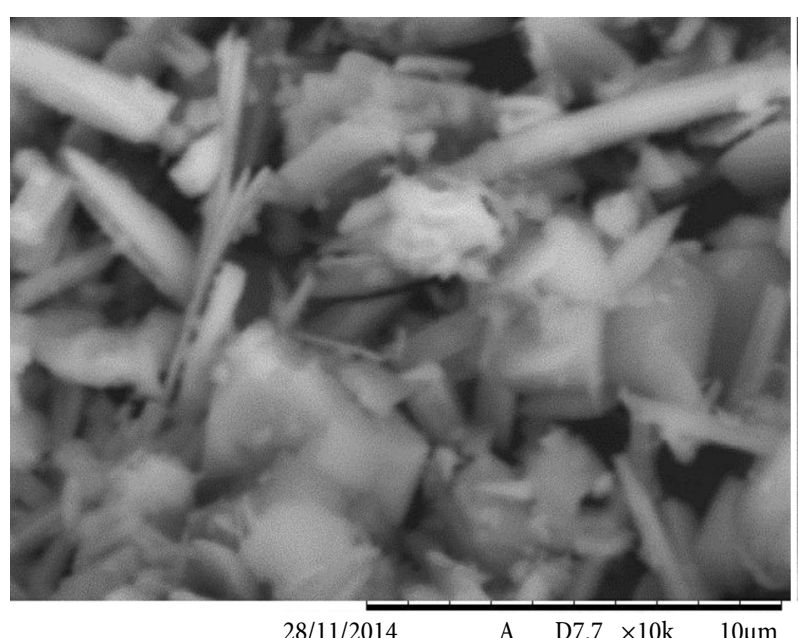

Fig. 4. SEM micrographs of crude (left) and recrystallized (right) iron (III) acetate. Magnification 10k $\times$.

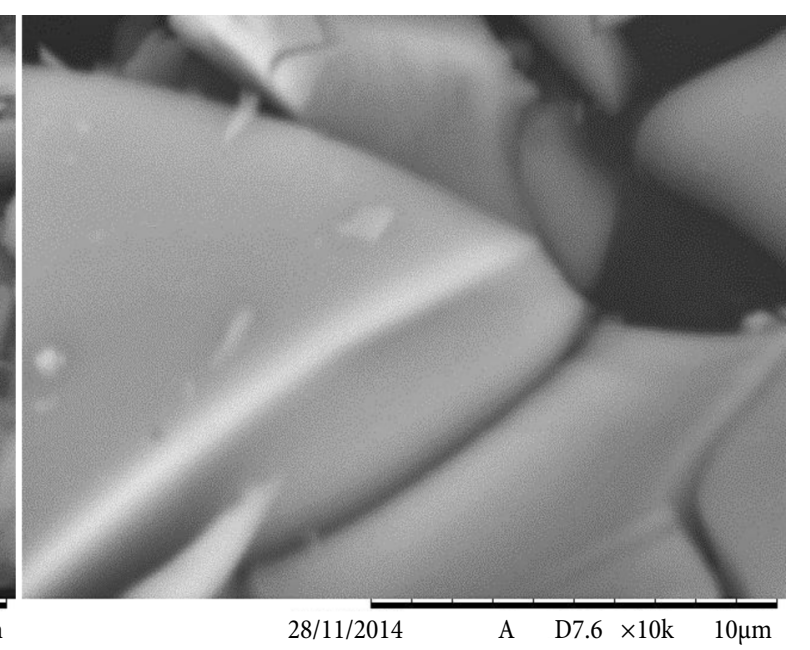

the infrared data [30, 31]. Besides, the infrared spectroscopy analysis also revealed some unidentified peaks in the FTIR spectra, the origin of which is not clear.

The SEM micrographs of the obtained iron (III) acetate are shown in Fig. 4 .

As seen, the crude iron (III) acetate sample is composed of irregular form rods $50-80 \mu \mathrm{m}$ in size. These microrods are partially covered with cloudy particles. However, the recrystallized iron (III) acetate sample shows a different surface microstructure. Apparently, sharp-edged plate-like particles about $85-100 \mu \mathrm{m}$ in size have formed during the recrystallization process. Energy-dispersive X-ray spectroscopy (EDX) was used for the determination of elemental composition of the synthesised sample (see Table 2).

Table 2. Elemental analysis data for $\mathrm{C}_{14} \mathrm{H}_{27} \mathrm{O}_{18} \mathrm{Fe}_{3}$ determined by EDX.

\begin{tabular}{c|c}
\hline Calculated \% & C, 26.96; O 46.18; Fe 26.86 \\
\hline Found \% & C, 27.04; O 45.63; Fe 27.33 \\
\hline
\end{tabular}

The results presented in Table 2 show a good agreement between the determined and calculated data.

Mössbauer spectroscopy was used for the characterization of crude and recrystallized iron (III) acetate samples. The Mössbauer spectra of the prepared and recrystallized iron (III) acetate samples are shown in Fig. 5 .

The Mössbauer spectrum of crude iron (III) acetate shows a doublet and a sextet. The recrystallized iron (III) acetate contains only a doublet. The areas of both subspectra and samples are similar. The hyperfine parameters of Mössbauer spectra of the prepared and recrystallized iron (III) acetate samples are summarized in Table 3. 


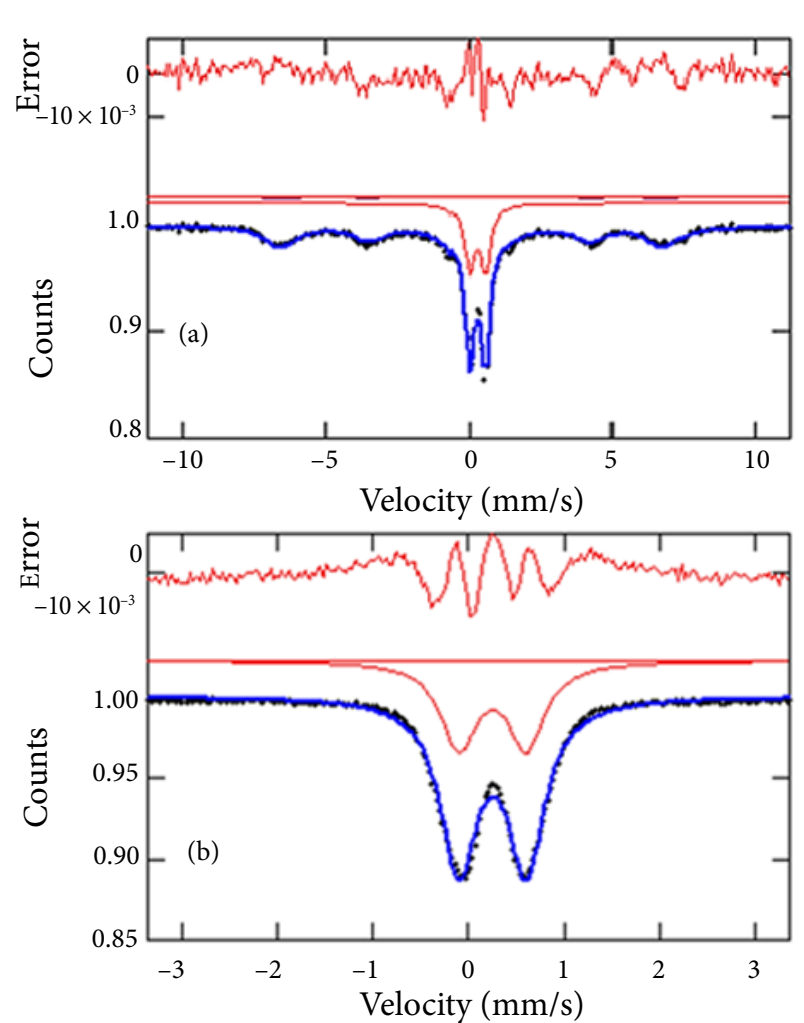

Fig. 5. (a) Mössbauer spectra of crude iron (III) acetate. (b) Mössbauer spectra of recrystallized iron (III) acetate.

Table 3. Hyperfine parameters of the Mössbauer spectra of the prepared and recrystallized iron (III) acetate samples. IS is isomer shift, QS is quadrupole splitting, $B_{\mathrm{hf}}$ is hyperfine splitting.

\begin{tabular}{c|cccc}
\hline & $\begin{array}{c}\text { Iron (III) } \\
\text { acetate } \\
\text { (crude) }\end{array}$ & $\begin{array}{c}\text { Iron (III) } \\
\text { acetate } \\
\text { (recrystallized) }\end{array}$ & Sextet \\
\hline $\mathrm{IS}, \mathrm{mm} / \mathrm{s}$ & $0.25 \pm 0.01$ & $0.25 \pm 0.01$ & $0.23 \pm 0.01$ \\
\hline $\mathrm{QS}, \mathrm{mm} / \mathrm{s}$ & $0.7 \pm 0.3$ & $0.6 \pm 0.3$ & $-0.2 \pm 0.3$ \\
\hline$B_{\mathrm{hf}}, \mathrm{T}$ & - & - & $42 \pm 4$ \\
\hline
\end{tabular}

According to literature [32] a doublet matches iron (III) acetate (IS $=0.29 \pm 0.02 \mathrm{~mm} / \mathrm{s}, \mathrm{QS}=0.63 \pm$ $0.03 \mathrm{~mm} / \mathrm{s})$. The sextet parameters are similar to the fine $(20 \mathrm{~nm}) \alpha-\mathrm{FeO}(\mathrm{OH})$ parameters (IS $=0.24 \mathrm{~mm} / \mathrm{s}$, $\left.\mathrm{QS}=-0.3 \mathrm{~mm} / \mathrm{s}, B_{\mathrm{hf}}=38.3 \mathrm{~T}\right)$. By theory, the quadrupole splitting (QS) is proportional to the electric field gradient (EFG). Iron (III) acetate does not display EFG if all ligands are the same. EFG is only observed on the $\mu-\mathrm{O}-\mathrm{Fe}-\mathrm{OH}_{2}$ axis. Also, such QS inaccuracies are related to relaxation (strongly coupled spin-system) or partial polymerization (different iron positions occur) by different authors.

The recrystallized iron (III) acetate was used as a precursor for the fabrication of iron metal-organic frameworks (MOFs).

The FTIR spectrum of $\mathrm{Fe}_{3} \mathrm{O}\left(\mathrm{F}_{4} \mathrm{BDC}\right)_{3}\left(\mathrm{H}_{2} \mathrm{O}\right)_{3}$. $(\mathrm{DMF})_{3.5}$ is shown in Fig. 6 .

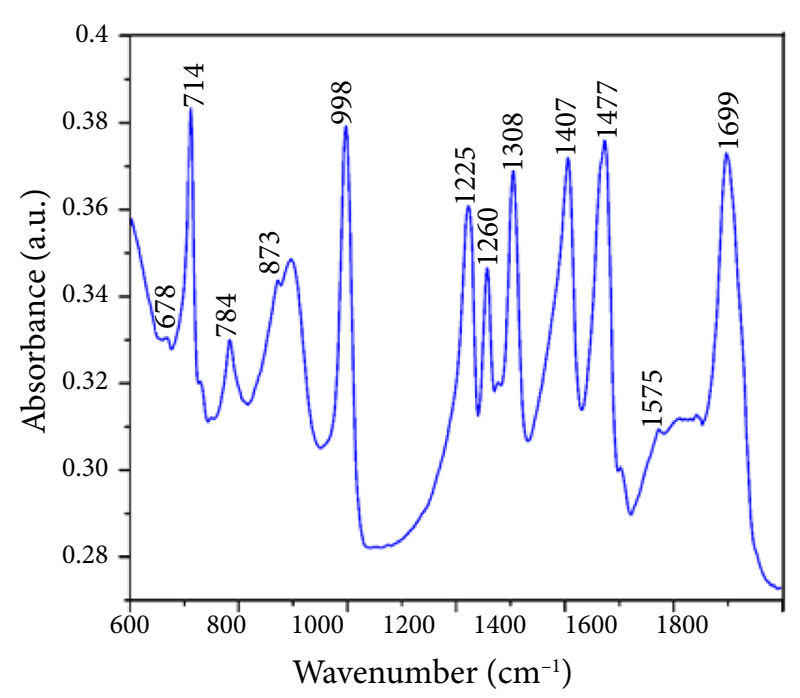

Fig. 6. The FTIR spectrum of $\mathrm{Fe}_{3} \mathrm{O}\left(\mathrm{F}_{4} \mathrm{BDC}\right)_{3}\left(\mathrm{H}_{2} \mathrm{O}\right)_{3}$. $(\mathrm{DMF})_{3.5}$.

The authors of Ref. [34] define that the framework of $\mathrm{Fe}_{3} \mathrm{O}\left(\mathrm{F}_{4} \mathrm{BDC}\right)_{3}\left(\mathrm{H}_{2} \mathrm{O}\right)_{3} \cdot(\overrightarrow{\mathrm{DMF}})_{3.5}$ has +1 charge per formula unit due to all iron having the oxidation state +3 , it is necessary for counter ions (acetate) to reside in the pores, limiting the pore volume. To reduce the average oxidation state of iron ions, iron (II) acetate could be used instead of iron (III) acetate as a precursor.

Solvothermal syntesis [33, 34] might improve the crystallinity and yield of the $\mathrm{Fe}_{3} \mathrm{O}\left(\mathrm{F}_{4} \mathrm{BDC}\right)_{3}\left(\mathrm{H}_{2} \mathrm{O}\right)_{3} \cdot(\mathrm{DMF})_{3.5}$ metal-organic framework.

\section{Conclusions}

According to this study, iron (III) acetate was synthesized using acetic acid/hydrogen peroxide type synthesis. The obtained iron (III) acetate was purified by recrystallization in $96.5 \%$ ethanol. The thermal decomposition behaviour of synthesized iron (III) acetate was investigated by thermogravimetric (TG) analysis. The weight loss in the TG curve was observed from room temperature to about $320^{\circ} \mathrm{C}$. Afterwards, the weight remains constant and that indicates that the decomposition of iron (III) acetate has been completed below $320^{\circ} \mathrm{C}$. The results of XRD analysis show that the synthesized iron (III) acetate is partially amorphous. The obtained iron (III) acetate sample was composed of irregular rods of $50-80 \mu \mathrm{m}$ in size. However, sharp-edged plate-like particles about 85$100 \mu \mathrm{m}$ in size have formed during the recrystallization process. Moreover, FTIR and Mössbauer spectroscopies revealed some unidentified features, which may result from impurities. The recrystallized iron (III) acetate was successfully used as a precursor for the fabrication of mixed-metal-organic frameworks (MOFs). 


\section{Acknowledgements}

This research was funded by Marie SkłodowskaCurie Research and Innovation Staff Exchange Grant (H2020-MSCA-RISE-2014 - TUMOCS) from the EU Framework Programme for Research and Innovation.

\section{References}

[1] K.I. Turte, S.G. Shova, V. Meriacre, M. Daniec, and Y.A. Simonov, Synthesis and structure of trinuclear iron acetate. J. Struct. Chem. 43, 108-117 (2002), http://dx.doi.org/10.1023/A:1016082018299

[2] B.N. Figgis and G.B. Robertson, Crystal-molecular structure and magnetic properties of $\mathrm{Cr}_{3}\left(\mathrm{CH}_{2} \mathrm{COO}\right) \mathrm{OCl} .5 \mathrm{H}_{2} \mathrm{O}$, Nature 205, 694-695 (1965), http://dx.doi.org/10.1038/205694a0

[3] J. Burgess and M.V. Twigg, in: Encyclopedia of Inorganic Chemistry, ed. R. Bruce King (2011), http://dx.doi.org/10.1002/0470862106.ia108

[4] R.C. Paul, R.C. Narula, and S.K. Vasisht, Iron (III) acetates, Trans. Metal Chem. 3, 35-38 (1978), http://dx.doi.org/10.1007/BF01393501

[5] K. Kluchova, R. Zboril, J. Tucek, M. Pecova, L. Zajoncova, I. Safarik, M. Mashlan, I. Markova, D. Jancik, and M. Sebela, Superparamagnetic maghemite nanoparticles from solid-state synthesis - Their functionalization towards peroral MRI contrast agent and magnetic carrier for trypsin immobilization, Biomaterials 30, 2855-2863 (2009), http://dx.doi. org/10.1016/j.biomaterials.2009.02.023

[6] J.R. Friedman and M.P. Sarachik, Single-molecule nanomagnets, Annu. Rev. Cond. Matter Phys. 1, 109-128 (2010), http://dx.doi.org/10.1146/annurev-conmatphys-070909-104053

[7] F.M. Duarte, FJ. Maldonado-Hodar, and L.M. Madeira, Influence of the iron precursor in the preparation of heterogeneous Fe/activated carbon Fentonlike catalysts, Appl. Catal. A 458, 39-47 (2013), http://dx.doi.org/10.1016/j.apcata.2013.03.030

[8] D. Nastou, B. Fernandez-Fernandez, U. Elewa, L. Gonzalez-Espinoza, E. Gonzalez-Parra, M.D. Sanchez-Nino, and A. Ortiz, Next-generation phosphate binders: Focus on iron-based binders, Drugs 74, 863-877 (2014), http://dx.doi.org/10.1007 540265-014-0224-6

[9] M. Diab and T. Mokari, Thermal decomposition approach for the formation of alpha- $\mathrm{Fe}_{2} \mathrm{O}_{3}$ mesoporous photoanodes and an alpha- $\mathrm{Fe}_{2} \mathrm{O}_{3} l$ $\mathrm{CoO}$ hybrid structure for enhanced water oxidation, Inorg. Chem. 53, 2304-2309 (2014), http:// dx.doi.org/10.1021/ic403027r

[10]Z.U. Rahman, Y.L. Dong, C.L. Ren, Z.Y. Zhang, and X.G. Chen, Protein adsorption on citrate modified magnetic nanoparticles, J. Nanosci. Nanotechnol. 12, 2598-2606 (2012), http://dx.doi.org/10.1166 inn.2012.5751
[11]T. Wang, S. Zhou, C.H. Zhang, J.B. Lian, Y. Liang, and W.X. Yuan, Facile synthesis of hematite nanoparticles and nanocubes and their shape-dependent optical properties, New J. Chem. 38, 46-49 (2014), http://dx.doi.org/10.1039/C3NJ01060K

[12] K.H. Shen, J.W. Wang, Y. Li, Y.S. Wang, and Y. Li, Preparation of magnetite core-shell nanoparticles of $\mathrm{Fe}_{3} \mathrm{O}_{4}$ and carbon with aryl sulfonyl acetic acid, Mater. Res. Bull. 48, 4655-4660 (2013), http:// dx.doi.org/10.1016/j.materresbull.2013.07.040

[13] M.Y. Zhu and G.W. Diao, Synthesis of porous $\mathrm{Fe}_{3} \mathrm{O}_{4}$ nanospheres and its application for the catalytic degradation of xylenol orange, I. Phys. Chem. C 115, 18923-18934 (2011), http://dx.doi. org/10.1021/jp200418;

[14]X. Pedro, J.J. Alvarez, Q. Li, Applications of nanotechnology in water and wastewater treatment, Water Res. 47, 3942 (2013), http://dx.doi. org/10.1016/j.watres.2012.09.058

[15] M.M. Pendergast and E.M.V. Hoek, A review of water treatment membrane nanotechnologies, Energy Environ. Sci. 4, 1946-1971 (2011), http:// dx.doi.org/10.1039/C0EE00541)

[16] M. Cazacu, A. Vlad, C. Turta, and G. Lisa, New ironcobalt clusters with silicon-containing dicarboxylic acids, Centr. Eur. J. Chem. 10, 1079-1086 (2012), http://dx.doi.org/10.2478/s11532-012-0022-5

[17]S.Kr. Das, S.P. Mahantaa, K.K. Bania, Oxidative coupling of 2-naphthol by zeolite-Y supported homo and heterometallic trinuclear acetate clusters, RSC Adv. 4, 51496-51509 (2014), http:// dx.doi.org/10.1039/C4RA10103K

[18] C.E. Sumner Jr, Interconversion of dinuclear and oxo-centered trinuclear cobaltic acetates, Inorg. Chem. 27, 1320-1327 (1988), http://dx.doi. org/10.1021/ic00281a004

[19]P. Rathi, D.P. Singh, and P. Surain, Synthesis, characterization, powder XRD and antimicrobial-antioxidant activity evaluation of trivalent transition metal macrocyclic complexes, Compt. Rendus Chem. 18, 430-437 (2015), http://dx.doi.org/10.1016/j. crci.2014.08.002

[20]N. Abdullah, M.H. Elsheikh, N.M.J.N. Ibrahim, S.M. Said, M.F.M. Sabri, M.H. Hassan, and A. Marlina, Magnetic, thermal, mesomorphic and thermoelectric properties of mononuclear, dimeric and polymeric iron(II) complexes with conjugated ligands, RSC Adv. 5, 50999-51007 (2015), http:// dx.doi.org/10.1039/c5ra07100c

[21] C.X. Yang, H.B. Ren, and X.P. Yan, Fluorescent metal organic framework MIL-53(Al) for highly selective and sensitive detection of $\mathrm{Fe}^{3+}$ in aqueous solution, Anal. Chem. 85, 7441-7446 (2013), http://dx.doi.org/10.1021/ac401387z

[22] M. Pilloni, F. Padella, G. Ennas, S.R. Lai, M. Bellusci, E. Rombi, F. Sini, M. Pentimalli, C. Delitala, and A. Scano, Liquid-assisted mechanochemical synthesis of an iron carboxylate metal organic frame- 
work and its evaluation in diesel fuel desulfurization, Micropor. Mesopor. Mater. 213, 14-21 (2015), http://dx.doi.org/10.1016/j.micromeso.2015.04.005

[23] S.K. Xian, J.J. Peng, Z.J. Zhang, Q.B. Xia, H.H. Wang, and Z. Li, Highly enhanced and weakened adsorption properties of two MOFs by water vapor for separation of $\mathrm{CO}_{2} / \mathrm{CH}_{4}$ and $\mathrm{CO}_{2} / \mathrm{N}_{2}$ binary mixtures, Chem. Eng. J. 270, 385-392 (2015), http://dx.doi. org/10.1016/j.cej.2015.02.041

[24]X.M. Quan, Y.D. Liu, and H.J. Choi, Magnetorheology of iron associated magnetic metal-organic framework nanoparticle, J. Appl. Phys. 117, 17C732 (2015), http://dx.doi.org/10.1063/1.4916110

[25] R. Sibille, T. Mazet, B. Malaman, Q.R. Wang, E. Didelot, and M. François, Site-dependent substitutions in mixed-metal metal-organic frameworks: A case study and guidelines for analogous systems, Chem. Mater. 27, 133-140 (2015), http://dx.doi. org/10.1021/cm503570

[26]I.E. Grey, H.E.A. Brand, M.S. Rumsey, and Y. Gozukara, Ultra-flexible framework breathing in response to dehydration in liskeardite, $\left[\left(\mathrm{Al}, \mathrm{Fe}_{16}\right.\right.$ (As $\left.\left.\left.\mathrm{O}_{4}\right)_{9}(\mathrm{OH})_{21}\left(\mathrm{H}_{2} \mathrm{O}\right)_{11}\right)\right] \cdot 26 \mathrm{H}_{2} \mathrm{O}$, a natural open-framework compound, J. Solid State Chem. 228, 146-152 (2015), http://dx.doi.org/10.1016/j.jssc.2015.04.035

[27] M.A.A. Elmasry, A. Gaber, and E.M.H. Khater, Thermal decomposition of $\mathrm{Ni}(\mathrm{II})$ and $\mathrm{Fe}(\mathrm{III})$ acetate and their mixture, J. Therm. Anal. 47, 757-763 (1996), http://dx.doi.org/10.1007/BF01981811

[28]F. Quiles and A. Burneaus, Infrared and Raman spectra of alkaline-earth and copper (II) acetates in aqueous solutions, Vibr. Spectr. 16, 105-117 (1998), http://dx.doi.org/10.1016/S0924-2031(98)00004-6

[29] K. Nakamoto, Infrared and Raman Spectra of Inorganic and Coordination Compounds, Part B (John Wiley and Sons, Inc., New York, 1997), http://dx.doi.org/10.1002/9780470405840

[30]K. Ito and H.J. Bernstein, The vibrational spectra of the formiate, acetate, and oxalate ions, Canad. J. Chem. 4, 170-178 (1956), http://dx.doi. org/10.1139/v56-021

[31] K.M. Parida, T. Mishra, D. Das, and S.N. Chintalpudi, Thermal transformation of trinuclear Fe (III) acetate complex intercalated montmorillonite, Appl. Clay Sci. 15, 463-475 (1999), http://dx.doi. org/10.1016/S0169-1317(99)00035-6

[32] N. Malathi and S.P. Puri, Mössbauer-effect study of iron (III) acetate and its chloro-derivatives, J. Phys. Soc. Jpn. 29, 108-111 (1970), http://dx.doi. org/10.1143/JPSJ.29.108

[33] J.H. Yoon, S.B. Choi, Y.J. Oh, M.J. Seo, and Y.H. Jhon, A porous mixed-valent iron MOF exhibiting the acs net: Synthesis, characterization and sorption behavior of $\mathrm{Fe}_{3} \mathrm{O}\left(\mathrm{F}_{4} \mathrm{BDC}\right)_{3}\left(\mathrm{H}_{2} \mathrm{O}\right)_{3}(\mathrm{DMF})$, Catal. Today 120, 326-327 (2007), http://dx.doi. org/10.1016/j.cattod.2006.09.003

[34] S. Zhang, Z. Jiao, and W. Yao, A simple solvothermal process for fabrication of a metal-organic framework with an iron oxide enclosure for the determination of organophosphorus pesticides in biological samples, J. Chrom. A 1371, 74-75 (2014), http://dx.doi.org/10.1016/j.chroma.2014.10.088

\title{
GELEŽIES (III) ACETATO, POTENCIALIOS PRADINĖS MEDŽIAGOS METALOORGANINĖMS STRUKTŪROMS (MOFs) GAUTI, SINTEZĖS YPATUMAI
}

\author{
A. Laurikènas a , J. Barkauskas ${ }^{\text {a }}$, J. Reklaitis ${ }^{\text {b }}$, G. Niaura ${ }^{\text {c }}$, D. Baltrūnas ${ }^{\text {b }}$, A. Kareiva ${ }^{\text {a }}$ \\ ${ }^{a}$ Vilniaus universiteto Neorganinès chemijos katedra, Vilnius, Lietuva \\ ${ }^{\mathrm{b}}$ Fiziniu ir technologijos mokslu centro Fizikos institutas, Vilnius, Lietuva

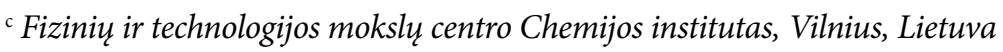

\begin{abstract}
Santrauka
Aprašyta, kaip acto rūgšties / vandenilio peroksido metodu susintetintas ir pakartotinai $96,5 \%$ etanolyje iškristalintas geležies (III) acetatas. Susintetinti ir pakartotinai kristalinti pavyzdžiai buvo ištirti termogravimetrinès (TG) analizès, rentgeno spindulių difrakcinès (XRD) analizès, Fourier transformacijos infraraudonosios (FTIR) spektroskopijos, skenuojančios elektroninès mikroskopijos (SEM) ir Mössbauer spektroskopijos metodais. Nustatyta, kad geležies (III) acetato terminis skilimas oro atmosferoje baigiasi ties $320^{\circ} \mathrm{C}$. Ištirtas ir
\end{abstract}

aptartas geležies (III) acetato fazinis grynumas bei kristališkumas. XRD tyrimų rezultatai leido padaryti išvadą, kad susintetintas geležies (III) acetatas buvo iš dalies amorfinis. Susintetintas geležies (III) acetatas buvo sudarytas iš nereguliarių $50-80 \mu \mathrm{m}$ dydžio strypelių. Tačiau perkristalinus, etanolyje buvo gauti 85-100 $\mu \mathrm{m}$ dydžio plokštuminiai kristalitai. Parodyta, kad taip susintetintas geležies (III) acetatas gali būti sèkmingai panaudotas kaip pradinè medžiaga metalo organinèms struktūroms (MOFs) gauti. 